\title{
Analisis Metode Capital Asset Pricing Model Sebagai Dasar Pengambilan Keputusan Investasi Pada Perusahaan Perbankan Yang Terdaftar Di Bursa Efek Indonesia (BEI)
}

\author{
Nia Nurhayati ${ }^{1}$, Agus Mulyani ${ }^{2}$, M. Kurniawan ${ }^{3}$, llhamsyah ${ }^{4}$ \\ ${ }^{1}$ Fakultas Ekonomi dan Bisnis Universitas PGRI Palembang, trinurjanah12@gmail.com \\ ${ }^{2}$ Fakultas Ekonomi dan Bisnis Universitas PGRI Palembang, agusmulyani@univpgri-palembang.ac.id \\ ${ }^{3}$ Fakultas Ekonomi dan Bisnis Universitas PGRI Palembang, iwanusman220506@gmail.com \\ ${ }^{4}$ Fakultas Ekonomi dan Bisnis Universitas PGRI Palembang, ilhamsyah@univpgri-palembang.ac.id
}

\begin{abstract}
The method used in this study is a descriptive method with a quantitative approach. Sampling technique in this research is to use porpusive sampling. The sample selected in this study were 4 companies from the banking sector belonging to State-Owned Enterprises (BUMN), which were listed on the Indonesia Stock Exchange (IDX) continuously in the 2015-2017 period. The results of the analysis that have been carried out show that the average rate of return on individual shares (Ri) of 4 shares of banking companies owned by State-Owned Enterprises (BUMN) is greater than the average market rate of return $(R m)$. While the average risk of 4 banking companies owned by State-Owned Enterprises (BUMN) there are 2 banking companies with risk below 1 ( $\beta i<1)$, namely Bank BNI and Bank BTN, then 2 banking companies with risk above 1 ( $\beta i>1$ ). And the average interest rate of Bank Indonesia is at $0.51 \%$ which is the risk-free rate of return (Rf). Furthermore, by using the Capital Asset Pricing Model (CAPM) analysis method, the results obtained from the estimation that of the 4 shares of banking companies owned by State-Owned Enterprises (BUMN), there are 2 banking companies that are classified as efficient stocks, namely Bank BNI and Bank BTN shares, while The other 2 banking companies, namely Bank BRI and Bank Mandiri, were classified as inefficient stocks during this period.
\end{abstract}

Keywords: Capital Asset Pricing Model Method and Investment Decision Making

\begin{abstract}
ABSTRAK
Metode yang digunakan dalam penelitian ini adalah metode deskriptif dengan pendekatan kuantitatif. Teknik pengambilan sampel dalam penelitian ini adalah dengan menggunakan porpusive sampling. Sampel yang dipilih dalam penelitian ini adalah 4 perusahaan dari sektor perbankan milik Badan Usaha Milik Negara (BUMN), yang terdaftar di Bursa Efek Indonesia (BEI) secara terus menerus pada periode 2015-2017. Hasil analisis yang telah dilakukan menunjukkan hasil bahwa rata-rata tingkat pengembalian saham individu (Ri) dari 4 saham dari perusahaan perbankan milik Badan Usaha Milik Negara (BUMN) lebih besar dari pada rata-rata tingkat pengembalian pasar (Rm). Sedangkan ratarata risiko 4 perusahaan perbankan milik Badan Usaha Milik Negara (BUMN) terdapat 2 perusahaan perbankan dengan risiko di bawah $1(\beta i<1)$, yaitu Bank BNI dan Bank BTN selanjutnya 2 perusahaan perbankan dengan risiko di atas $1(\beta i>1)$. Serta rata-rata tingkat suku bunga Bank Indonesia berada pada $0.51 \%$ yang merupakan tingkat pengembalian bebas risiko (Rf). Selanjutnya dengan menggunakan metode analisis Capital Asset Pricing Model (CAPM), diperoleh hasil dari estimasi bahwa dari 4 saham perusahaan perbankan milik Badan Usaha Milik Negara (BUMN), terdapat 2 perusahaan perbankan yang tergolong saham efisien, yaitu saham Bank BNI dan Bank BTN, sedangkan 2 perusahaan perbankan lainnya, yaitu Bank BRI dan Bank Mandiri tergolong saham yang tidak efisien pada periode ini.
\end{abstract}

Kata Kunci: Metode Capital Asset Pricing Model dan Pengambilan Keputusan Investasi

\section{A. PENDAHULUAN}

Dalam perkembangan dunia usaha, perusahaan sangat bergantung terhadap investasi. Investasi memberikan pengembangan sebuah usaha yang dijalankan. 
Tujuan dilakukannya investasi adalah untuk mendapatkan keuntungan yang lebih besar daripada yang diinvestasikan sekarang.

Investasi dapat berupa investasi riil maupun investasi financial. Investasi riil berbentuk fasilitas yang berkaitan dengan kegiatan produksi perusahaan, seperti tanah, bangunan, peralatan, dan lain-lain. Sedangkan investasi financial hanya merupakan bukti kepemilikan perusahaan, tetapi tidak memiliki kontribusi langsung terhadap produksi perusahaan, seperti saham, obligasi, dan surat-surat berharga lainnya.

Investasi adalah komitmen atas sejumlah dana atau sumber daya lainnya yang dilakukan pada saat ini, dengan tujuan untuk memperoleh sejumlah keuntungan di masa datang. Harapan keuntungan (return) di masa datang tersebut merupakan kompensasi atas waktu dan resiko yang terkait dengan investasi yang dilakukan. Semua investasi mengandung unsur ketidakpastian atau resiko. Ketidakpastian tersebut membuat investor hanya dapat memperkirakan beberapa tingkat keuntungan yang diharapkan dari investasi yang dilakukan, dan seberapa jauh kemungkinan hasil yang sebenarnya nanti akan menyimpang dari hasil yang diharapkan. Salah satu karakteristik investasi pada sekuritas adalah kemudahan untuk membentuk portofolio investasi. Artinya pemodal dapat dengan mudah menyebar (melakukan diverifikasi) investasinya pada berbagai kesempatan investasi.

Untuk memudahkan pengumpulan dana dari masyarakat yang ingin berinvestasi, maka dibutuhkan suatu wadah kegiatan investasi yang disebut dengan pasar modal. Di Indonesia, pasar modal yang membawahi kegiatan jual-beli surat berharga adalah Bursa Efek Indonesia (BEI). Bursa Efek Indonesia (BEI) merupakan wadah bagi pelaku saham untuk memperjualbelikan setiap saham/efek yang dimiliki pelaku saham. Perusahaan yang terdaftar dan menjual sahamnya di Bursa Efek Indonesia (BEI) merupakan perusahaan yang sudah Go Public atau perusahaan terbuka. Saham-saham yang terdaftar di Bursa Efek Indonesia (BEI) akan tercantum pada IHSG (Indeks Harga Saham Gabungan).

Harapan seorang investor dalam berinvestasi adalah menginginkan return (pengembalian) yang tinggi dengan resiko yang serendah mungkin. Untuk melakukan keputusan investasi yang optimal, perlu dilakukan perhitungan estimasi atas return yang akan didapat di masa yang akan datang. Salah satu metode perhitungan estimasi dalam menilai kelayakan investasi adalah dengan menggunakan metode CAPM (Capital Asset Pricing Model).

Metode Capital Asset Pricing Model (CAPM) merupakan salah satu model keseimbangan yang dapat menentukan hubungan antara tingkat return dari suatu asset beresiko, dengan resiko dari asset tersebut pada kondisi pasar yang seimbang. Pada metode CAPM, portofolio pasar sangat berpengaruh karena diasumsikan bahwa resiko yang relevan adalah risiko sistematis yang diukur dengan beta (tingkat sensitivitas return sekuritas terhadap perubahan return pasar).

Di dalam Bursa Efek Indonesia (BEI), terdapat salah satu sektor yang menjadi objek penelitian, yaitu sektor perbankan yang terdaftar di Bursa Efek Indonesia (BEI). Bursa Efek Indonesia (BEl) menilai, sepanjang perekonomian Indonesia masih tumbuh akan mendorong saham sektor perbankan dinilai masih positif. Kinerja saham sektor keuangan dan perbankan yang tercatat di pasar modal Indonesia cukup positif, yang tercermin dalam Indeks Harga Saham Gabungan (IHSG) Bursa Efek Indonesia (BEI). 
Sektor perbankan dapat menjadi salah satu alternatif dalam investasi oleh investor, dengan melihat prospek perbankan yang sudah dipaparkan di atas, karena dunia investasi dan pasar modal selalu menjadi topik pembahasan menarik di era globalisasi seperti saat ini. Saham perbankan juga dapat menjadi patokan dalam berinvestasi, maka saham-saham perusahaan perbankan di Bursa Efek Indonesia (BEI) banyak diminati oleh para investor, yang mengakibatkan saham-saham perbankan cukup banyak yang memiliki kategori sebagai saham unggulan.

\section{B. KAJIAN TEORI}

\section{1) Pengertian Investasi}

Investasi merupakan komitmen atas sejumlah dana atau sumberdaya yang dilakukan pada saat ini, dengan tujuan memperoleh sejumlah keuntungan di masa yang akan datang (Tandelilin, 2010:2).

Sedangkan menurut Jagiyanto (2016:5) invetasi pada dasarnya dilakukan dengan maksud mengharapkan sejumlah keuntungan di masa datang, dengan menanam modal di masa sekarang. Investasi merupakan penundaan konsumsi sekarang untuk digunakan di dalam produksi yang efisien selama periode waktu tertentu. Investasi dapat didefinisikan sebagai setiap kegiatan yang meningkatkan kemampuan ekonomi untuk memproduksi output di masa yang akan datang, dan hal ini sangat mempengaruhi sumbangan sektor perbankan terhadap pembangunan ekonomi, yang dapat dilihat besarnya sumbangan pada PDB (Produk Domestik Bruto). Hal ini menunjukkan bahwa, bank mempunyai sumbangan yang cukup berarti bagi pertumbuhan PDB (Produk Domestik Bruto) di Indonesia.

Menurut Abdul Halim dalam Fahmi (2013:3), investasi merupakan penempatan sejumlah dana pada saat ini dengan harapan untuk memperoleh keuntungan di masa mendatang.

Berdasarkan definisi di atas, dapat disimpulkan bahwa investasi merupakan komitmen atas sejumlah dana atau sumberdaya yang dilakukan pada saat ini, dengan maksud mengharapkan sejumlah keuntungan selama periode waktu tertentu.

\section{2) Tujuan Investasi}

Menurut Fahmi (2013:3) untuk mencapai suatu efektivitas dan efesiensi dalam keputusan, maka diperlukan ketegasan akan tujuan yang diharapkan. Begitu pula halnya dalam bidang investasi, perlu menetapkan tujuan yang hendak dicapai yaitu:

$>$ Terciptanya keberlanjutan (continuity) dalam investasi tersebut.

$>$ Terciptanya profit yang maksimal atau keuntungan yang di harapkan.

$>$ Terciptanya kemakmuran bagi pemegang saham.

$>$ Turut memberikan andil bagi pengembang bangsa.

\section{3) Bentuk-Bentuk Investasi}

Menurut Hadi (2013:7) bentuk-bentuk investasi pada umumnya dikenal ada dua bentuk, yaitu:

$>$ Investasi nyata (rill investment), secara umum melibatkan asset berwujud, seperti tanah, mesin-mesin atau pabrik.

$>$ Investasi keuangan (financial investment), melibatkan kontrak tertulis, seperti saham biasa (command stock) dan obligasi (bond).

\section{4) Tipe-Tipe Investasi}

Menurut Jagiyanto $(2014 ; 7)$ pada saat seorang pebisnis atau yang memiliki kelebihan dan ingin berinvestasi, maka orang tersebut dapat memilih dan 
memutuskan tipe aktiva keuangan seperti apa yang akan dipilih. Dalam hal ini, ada dua tipe investasi yang dapat dipilih yaitu:

a. Investasi Langsung Investasi langsung (direct investment), adalah orang yang memiliki dana yang dapat langsung berinvestasi, dengan membeli secara langsung suatu aktiva keuangan dari suatu perusahaan, yang dapat dilakukan baik melalui para perantara atau berbagai cara lainnya.

b. Investasi Tidak Langsung

Investasi tidak langsung (indirect investment), adalah orang yang memiliki kelebihan dana, yang dapat melakukan keputusan investasi dengan tidak terlibat secara langsung, atau pembelian aktiva keuangan yang cukup hanya dengan memegang dalam bentuk saham atau obligasi saja.

\section{5) Proses Investasi}

Setiap melakukan keputusan investasi, selalu memerlukan proses yang memberikan gambaran pada setiap tahap yang akan ditempuh oleh perusahaan. Menurut Suad (2012:47) proses investasi meliputi 5 (lima) langkah, yaitu sebagai berikut:

$>$ Menentukan Kebijakan Investasi

$>$ Melakukan Analisis Sekuritas

$>$ Melakukan Pembentukan Portofolio

$>$ Melakukan Revisi Kinerja Portofolio

$>$ Melakukan Evaluasi Kinerja Portofolio

\section{6) Pengertian Bank}

Menurut Ismail (2011:3), bank merupakan lembaga perantara keuangan bagi masyarakat, dengan cara menghimpun dana dari masyarakat yang kelebihan dana (surplus unit), kemudian setelah dana terkumpul, bank segera menyalurkan dana tersebut kepada masyarakat yang sedang membutuhkan dana (defisit unit).

Menurut Undang-Undang Perbankan Nomor 10 Tahun 1998, yang dimaksud dengan bank adalah "badan usaha yang menghimpun dana dari masyarakat dalam bentuk simpanan dan menyalurkannnya kepada masyarakat dalam bentuk kredit dan atau bentuk-bentuk lainnya dalam rangka meningkatkan taraf hidup rakyat banyak".

Berdasarkan pengertian-pengertian di atas, dapat dijelaskan secara lebih luas bahwa bank merupakan perusahaan yang bergerak dibidang keuangan, artinya aktivitas perbankan selalu berkaitan dalam bidang keuangan. Sehingga berbicara mengenai bank tidak terlepas dari masalah keuangan.

\section{7) Fungsi Bank}

Menurut Ismail (2011:3) ada tiga fungsi utama bank, yaitu menghimpun dana masyarakat, penyaluran dana kepada masyarakat, dan pemberian pelayanan jasa perbankan.

$>$ Menghimpun Dana Dari Masyarakat

$>$ Menyalurkan Dana Kepada Masyarakat

$>$ Pelayanan Jasa Perbankan

\section{8) Jenis-Jenis Bank}

Menurut Kasmir (2014:19), perbedaan jenis perbankan dapat dilihat dari segi fungsi, serta kepemilikannya. Dari segi fungsi, perbedaan yang terjadi terletak pada luasnya kegiatan, atau jumlah produk yang dapat ditawarkan, serta jangkauan 
wilayah operasinya. Sedangkan kepemilikan perusahaan dilihat dri segi kepemilikan sahamnya. Perbedaan lainnya adalah dilihat dari segi nasabah yang dilayani, apakah masyarakat luas atau masyarakat dalam lokasi tertentu (kecamatan). Jenis perbankan juga dibagi dalam menentukan harga jual, dan harga beli, atau dengan kata lain caranya mencari keuntungan. Adapun jenis perbankan jika ditinjau dari berbagai segi antara lain:

1. Dilihat dari Segi Fungsinya, dibagi menjadi:

a. Bank Umum

Bank umum adalah bank yang melaksanakan kegiatan usaha secara konvensional, dan sifat jasa yang diberikan adalah umum, dalam arti dapat memberikan seluruh jasa perbankan yang ada. Bank umum sering disebut juga bank komersil (commercial bank).

b. Bank Perkreditan Rakyat

Dalam kegiatannya, Bank Perkreditan Rakyat (BPR) tidak memberikan jasa dalam lalu lintas pembayaran. Artinya jasa-jasa perbankan yang ditawarkan Bank Perkreditan Rakyat jauh lebih sempit jika dibandingkan dengan kegiatan atau jasa bank umum.

2. Dilihat dari Segi Kepemilikannya, dibagi menjadi:

a. Bank Milik Pemerintah

Merupakan bank yang akte pendirian maupun modal bank ini sepenuhnya dimiliki oleh Pemerintah Indonesia. Kemudian Bank Pemerintah Daerah (BPD) terdapat di daerah tingkat I dan tingkat II masing-masing provinsi.

b. Bank Milik Swasta Nasional

Merupakan bank yang seluruh atau sebagian besar sahamnya dimiliki oleh swasta nasional. Kemudian akte pendiriannya pun didirikan oleh swasta.

c. Bank Milik Koperasi

Merupakan bank yang kepemilikan saham-sahamnya dimiliki oleh perusahaan yang berbadan hukum koperasi.

d. Bank Milik Asing

Bank jenis ini merupakan cabang dari bank yang ada diluar negeri, baik milik swasta asing atau pemerintah asing.

e. Bank Milik Campuran

Kepemilikan saham bank campuran dimiliki oleh pihak asing dan pihak swasta nasional. Kepemilikan sahamnya secara mayoritas dipegang oleh warga negara Indonesia.

3. Dilihat dari Segi Status, dibagi menjadi:

a. Bank Devisa

Merupakan bank yang dapat melaksanakan transaksi keluar negeri atau yang berhubungan dengan mata uang asing secara keseluruhan,

b. Bank Non Devisa

Merupakan bank yang belum mempunyai izin untuk melaksanakan transaksi sebagai bank devisa.Jadi bank non devisa merupakan kebalikan daripada bank devisa, di mana transaksi yang dilakukan masih dalam batas-batas Negara.

4. Dilihat Dari Segi Cara Menentukan Harga, dibagi menjadi:

a. Bank yang Berdasarkan Prinsip Konvensional (Barat)

Yaitu bank yang dalam mencari keuntungan dan menentukan harga kepada para nasabahnya menggunakan metode penetapan bunga sebagai harga, 
untuk produk simpanan seperti giro, tabungan maupun deposito. Demikian pula harga untuk produk pinjamannya (kredit) juga ditentukan berdasarkan tingkat suku bunga tertentu.

b. Bank yang Berdasarkan Prinsip Syariah (Islam)

Bank yang berdasarkan prinsip syariah adalah pembiayaan berdasarkan prinsip bagi hasil (mudharabah), pembiayaan berdasarkan prinsip penyertaan modal (musyarakah), prinsip jual beli barang dengan memperoleh keuntungan (murabahah), pembiayaan barang modal berdasarkan sewa murni tanpa pilihan (ijarah), atau dengan adanya pemilihan pemindahan kepemilikan atas barang yang disewa dari pihak bank oleh pihak lain (ijarah wa iqtina).

\section{9) Pengertian Pasar Modal}

Menurut Jagiyanto (2014:33) pasar modal merupakan suatu situasi dimana para penjual dan pembeli dapat melakukan negosiasi terhadap pertukaran suatu komoditas atau kelompok komoditas dan komoditas yang dipertukarkan disini adalah modal.

Sedangkan Menurut Tandelilin (2010:26) pasar modal adalah pertemuan antara pihak yang memiliki kelebihan dana dengan pihak yang membutuhkan dana dengan cara memperjualbelikan sekuritas.

Berdasarkan beberapa pendapat diatas dapat dijelaskan bahwa pasar modal adalah pertemuan antara pihak yang memiliki kelebihan dana dengan pihak yang membutuhkan dana dengan cara memperjualbelikan sekuritas atau efek.

\section{0) Jenis Pasar Modal}

Menurut Sunariyah (2011:12) jenis-jenis pasar modal tersebut ada beberapa macam, yaitu:

a. Pasar Perdana (Primary Market), adalah penawaran saham dari perusahaan yang menerbitkan saham (emitmen) kepada pemodal selama waktu yang ditetapkan oleh pihak sebelum saham tersebut diperdagangkan di pasar sekunder.

b. Pasar Sekunder (Secondary Market), adalah sebagai perdagangan saham setelah melewati masa penawaran pada pasar perdana.

c. Pasar Ketiga (Third Market), adalah tempat perdagangan saham atau sekuritas lain di luar bursa (over the counter market).

d. Pasar Keempat (Fourth Market), adalah bentuk perdagangan efek antar pemodal, atau dengan kata lain pengalihan saham dari satu pemegang saham ke pemegang lainnya tanpa melalui perantara perdagangan efek.

\section{1) Pengertian Saham}

Menurut Darmadji dan Fakhrudin (2011:49), saham didefinisikan sebagai tanda penyertaaan atau pemilikan seseorang atau badan dalam suatu perusahaan atau perseroan terbatas. Wujud saham adalah selembar kertas yang menerangkan bahwa pemilik ketas tersebut adalah pemilik perusahaan yang menerbitkan surat berharga tersebut.

Menurut Tandelilin (2010:31) saham merupakan sertifikat yang menunjukan bukti kepemilikan suatu perusahaan dan pemegang saham memiliki hak klaim atas penghasilan dan aset perusahaan.

Berdasarkan pendapat diatas dapat disimpulkan bahwa sebagai tanda penyertaan atau kepemilikan saham atau badan dalam suatu perusahaan dan suatu perusahaan tersebut dapat menjual hak kepemilikannya dalam bentuk saham. 


\section{2) Pengertian Return}

Menurut Jagiyanto (2016:263), return adalah hasil yang diperoleh dari investasi. Return dapat berupa return realisasian (realized return) yang sudah terjadi, atau return ekspektasi (expected return) yang belum terjadi, tetapi yang diharapkan akan terjadi di masa mendatang.

Sedangkan menurut Fahmi (2013:189), return adalah keuntungan yang diperoleh oleh perusahaan, individu dan institusi dari hasil kebijakan investasi yang dilakukannya.

Komponen laba atas investasi, terdiri dari yield dan capital gain. Yield merupakan bagian laba yang didapat sebesar kepemilikan saham. Sedangkan capital gain adalah selisih antara harga beli dan harga pasar saat ini. Pencapaian sebuah keuntungan akan diperoleh dengan mencermati seberapa besar tingkat keuntungan yang dihadapi. Tingkat keuntungan tersebut antara lain tingkat pengembalian saham individu (Ri), tingkat pengembalian pasar $(\mathrm{Rm})$, dan tingkat pengembalian bebas risiko (Rf). Tingkat pengembalian (return) menunjukkan besarnya keuntungan atau kerugian transaksi perdagangan saham yang dihitung secara bulanan. Sedangkan tingkat pengembalian pasar merupakan tingkat pengembalian yang didasarkan pada perkembangan indeks harga saham. Kemudian tingkat pengembalian bebas risiko merupakan angka atas tingkat pengembalian atas asset finansial yang tidak berisiko. Di samping besarnya manfaat return yang dapat dinikmati investor, terdapat kemungkinan risiko yang akan terjadi.

Menurut Fahmi (2013:189), risiko dapat ditafsirkan sebagai bentuk keadaan ketidakpastian tentang suatu keadaan yang akan terjadi nantinya (future), dengan keputusan yang akan diambil berdasarkan berbagai pertimbangan pada saat ini. Selanjutnya menurut Utami (2010:45), risiko ini dapat berupa melesetnya imbal hasil dari nilai ekspektasi, ketidakjelasan imbal hasil di masa mendatang, dan kemungkinan hasil yang berlawanan. Risiko yang dihadapi, di antaranya adalah:

a. Tidak Ada Pembagian Deviden

b. Capital Loss

c. Risiko likuiditas

d. Saham Delisting dari Bursa

Risiko memiliki beberapa jenis yang memiliki karakteristik yang berbeda, yaitu risiko sistematis dan risiko tidak sistematis. Risiko sistematis adalah risiko yang tidak dapat dihindari, sedangkan risiko tidak sistematis adalah risiko yang dapat dihindari atau dapat diverifikasi.

\section{3) Pengertian Beta ( $\beta)$}

Menurut Jagiyanto (2014:443) bata merupakan suatu pengukur volatilitas volatility) return suatu sekuritas atau return portofolio terhadap return pasar. Besarnya suatu saham ditentukan oleh beta. Dalam pembahasan metode Capital Asset Pricing Model (CAPM) dan berbagai rumus yang diterapkan beta, selalu dipergunakan. Beta $(\beta)$ diartikan sebagai risiko saham sistematis.

$\beta>1 \quad$ Ini menunjukan harga saham perusahaan adalah lebih mudah berubah di bandingkan indeks pasar.

$\beta<1$ Ini menunjukan tidak terjadinya kondisi yang mudah berubah berdasarkan kondisi pasar.

$\beta=1 \quad$ Ini menunjukan bahwa kondisinya sama dengan indeks pasar.

Pada saat $\beta>1$ ini, menunjukan kondisi saham menjadi lebih berisiko, dalam artian jika pada saat terjadinya perubahan pasar sebesar $1 \%$ maka pada saham $X$ akan mengalami perubahan lebh besar $1 \%$ atau saham $X>1 \%$. 


\section{4) Pengertian Metode Capital Asset Pricing Model}

Menurut Suad (2012:177) metode Capital Asset Pricing Model merupakan metode untuk menentukan harga suatu asset. Metode ini mendasarkan diri pada kondisi ekuilibrium. Dalam kondisi ekuilibrium, tingkat keuntungan yang disyaratkan oleh pemodal untuk suatu saham akan dipengaruhi oleh risiko saham tersebut.

Sedangkan menurut William F. Sharpe, et. All dalam Fahmi (2013:288) metode Capital Asset Pricing Model merupakan metode penetapan harga aktiva equilibrium yang menyatakan bahwa ekspektasi return atas sekuritas tertentu adalah fungsi linier positif dari sensitivitas sekuritas terhadap perubahan return portofolio pasarnya.

Lebih lanjut lagi, menurut Halim (2015:75) metode Capital Asset Pricing Model merupakan metode untuk menentukan harga suatu assets pada kondisi ekuilibrium. Tujuannya untuk menentukan minimum required return dari investasi-investasi yang berisiko.

Berdasarkan pendapat-pendapat di atas, dapat disimpulkan bahwa metode Capital Asset Pricing Model adalah metode keseimbangan yang menggambarkan hubungan risiko dan return untuk menentukan harga suatu asset terhadap perubahan return portofolio pasar.

\section{5) Asumsi-Asumsi Menggunakan Metode Capital Asset Pricing Model}

Seperti halnya teori-teori keuangan yang lainnya, asumsi dilakukan untuk memberi kemudahan bagi banyak pihak.Asumsi-asumsi diperlukan supaya suatu model lebih mudah dipahami.

Menurut Jagiyanti (2014:556) asumsi-asumsi yang digunakan di metode Capital Asset Pricing Model (CAPM) adalah sebagai berikut:

a. Investor mengevaluasi portofolio dengan melihat return yang diharapkan, dan simpangan baku portofolio pada rentang satu periode;

b. Investor tidak pernah puas, jika diberi pilihan antara dua portofolio yang simpangan bakunya identik, investor akan memilih portofolio yang memberi return yang diharapkan lebih tinggi.

c. Investor adalah risk adverse, jika diberi pilihan antara dua portofolio dengan return yang diharapkan identik, investor akan memilih portofolio dengan simpangan baku yang lebih rendah.

d. Aset individual dapat dibagi tidak terbatas, artinya investor dapat membeli sebagian saham jika investor berminat.

e. Terdapat tingkat bebas risiko, yang pada tingkat itu investor dapat memberi pinjaman (berinvestasi) atau meminjam uang.

f. Pajak dan biaya transaksi tidak relevan.

16) Pengelompokkan Saham Yang Efisien Berdasarkan Metode Capital Asset Pricing Model

Menurut Jagiyanto (2014:44), saham yang efisien adalah saham-saham dengan tingkat pengembalian individu lebih besar dari tingkat pengembalian yang diharapkan $[(\mathrm{Ri})>\mathrm{E}(\mathrm{Ri})]$. Keputusan investasi terhadap saham yang efesien maupun tidak efisien adalah sebagai berikut:

a. Saham Efisien

Keadaan saham efisien menunjukkan bahwa tingkat pengembalian saham individu (Ri) lebih besar daripada tingkat pengembalian yang diharapkan [E(Ri)]. 
b. Saham Tidak Efisien

Keadaan saham tidak efisien menunjukkan bahwa tingkat pengembalian individu (Ri) lebih kecil daripada tingkat pengembalian yang diharapkan.

\section{7) Pengertian Pengembalian Keputusan}

Menurut Fahmi (2013:38) pengambilan keputusan adalah proses penelusuran masalah yang berawal dari latar belakang masalah, identifikasi masalah, hingga kepada terbentuknya kesimpulan atau rekomendasi. Rekomendasi atau kesimpulan inilah yang selanjutnya akan dapat digunakan sebagai pedoman basis dalam pengambilan keputusan. Oleh karena itu, besarnya pengaruh yang akan terjadi jika rekomendasi yang dihasilkan tersebut terdapat kekeliruan atau adanya kesalahankesalahan yang tersembunyi, karena faktor ketidakhati-hatian dalam melakukan pengkajian masalah.

Dalam pengambilan keputusan ini, dikenal tahap-tahap yang diikuti dalam proses pengambilan keputusan yang umum, yaitu sebagai berikut:

> Mengidentifikasi persoalan dengan cara membandingkan keinginan dengan kejadian yang sebenarnya.

$>$ Merumuskan persoalan utama.

$>$ Merincikan persoalan.

$>$ Merumuskan berbagai alternatif pemecahan.

$>$ Memutuskan pilihan terbaik.

$>$ Melaksanakan.

> Memonitor dan menindaklanjuti.

\section{METODE PENELITIAN}

1) Variabel Penelitian

Menurut Sugiyono (2017:60) variabel penelitian adalah segala sesuatu yang berbentuk apa saja, yang ditetapkan oleh peneliti untuk dipelajari sehingga diperoleh informasi tentang hal tersebut, kemudian ditarik kesimpulannya. Penelitian ini terdiri dari 1 variabel, yaitu metode Capital Asset Pricing Model.

\section{2) Definisi Operasional Istilah}

Definisi operasional adalah untuk memahami arti variabel penelitian sebelum dilakukan analisis (Sujarweni, 2014:87). Definisi operasional variabel dalam penelitian ini adalah:

Metode Capital Asset Pricing Model adalah metode penetapan harga aktiva equilibrium yang menyatakan bahwa ekspektasi return atas sekuritas tertentu adalah fungsi linier positif dari sensitivitas terhadap perubahan return portofolio pasarnya (Fahmi 2013:288). Rumus yang digunakan dalam metode Capital Asset Pricing Model adalah:
a. $\mathrm{Ri}=\frac{(\mathrm{Pt}-\mathrm{Pt}-1)+\mathrm{D}}{\mathrm{Pt}-1}$
b. $R m=$ IHSGt - IHSGt-1
c. $R_{f}=\frac{\sum \mathrm{SBI}}{\mathrm{N}}$
IHSGt-1
d. $\left.E\left(R_{i}\right)=R_{f}+\left\{E R_{m}\right)-R_{f}\right\} \beta i$
e. $\beta i=\frac{\sigma_{i} m}{\sigma^{2 m}}$

\section{3) Populasi dan Sampel}

a. Populasi Penelitian 
Menurut Sugiyono (2017:117), populasi adalah wilayah generalisasi yang terdiri atas: objek/subyek yang mempunyai kualitas dan karekteristik tertentu yang ditetapkan oleh peneliti untuk dipelajari, dan kemudian ditarik kesimpulannya.

Berdasarkan pendapat di atas, populasi dalam penelitian ini adalah seluruh perusahaan perbankan yang terdaftar di Bursa Efek Indonesia (BEI), yaitu 43 perusahaan perbankan pada tahun 2015 - 2017.

b. Sampel Penelitian

Menurut Sugiyono (2017:118) sampel adalah bagian dari jumlah dan karakteristik yang dimiliki oleh populasi. Teknik pengambilan sampel dalam penelitian ini adalah dengan menggunakan porpusive sampling.

Menurut Sujarweni (2014:72) teknik porpusive sampling adalah teknik penentuan sampel dengan pertimbangan atau kriteria-kriteria tertentu.

Teknik porpusive sampling menciptakan kriteria-kriteria tertentu, yang digunakan sebagai teknik pengumpulan sampel, sehingga dapat memberikan informasi sesuai dengan tujuan penelitian.

Kriteria-kriteria yang digunakan dalam proses pemilihan sampel pada penelitian ini adalah sebagai berikut:

1. Sampel yang digunakan dalam penelitian ini adalah 4 perusahaan perbankan milik BUMN, yang terdiri dari bank BRI, BNI, BTN, dan Mandiri pada tahun 2015-2017.

2. Menyediakan laporan keuangan yang berisi informasi keuangan lengkap dari tahun 2015 sampai dengan 2017.

3. Menyediakan laporan ICMD (Indonesian Capital Market Directory) dari tahun 2015-2017.

4. Aktif membagi deviden selama tahun pengamatan.

\section{4) Sumber Data}

Data yang digunakan dalam penelitian ini bersumber dari data sekunder. Menurut Sugiyono (2017:402) sumber data sekunder adalah sumber data yang tidak langsung memberikan data kepada pengumpul data, misalnya lewat orang lain atau lewat dokumen.

Dalam penelitian ini, data yang digunakan adalah data sekunder yang terdiri dari data ICMD (Indonesian Capital Market Directory) periode 2015-2017 yang diperoleh dari Pojok Bursa Efek Indonesia Unika Musi Charitas, harga saham pada periode 2015-2017, dan data IHSG pada periode 2015-2017 di Bursa Efek Indonesia yang dipublikasikan oleh Indonesia Stock Exchange (IDX).

\section{5) Teknik Pengumpulan Data}

Menurut Sugiyono (2017:224), teknik pengambilan data merupakan langkah yang paling utama dalam penelitian, karena tujuan utama dari penelitian adalah mendapatkan data. Tanpa mengetahui teknik pengumpulan data, maka peneliti tidak akan mendapatkan data yang memenuhi standar data yang ditetapkan.

Menurut Sugiyono (2017:402), teknik pengumpulan data terdapat tiga cara yaitu, observasi, wawancara, dan dokumentasi.

1. Observasi

Observasi atau pengamatan langsung adalah pengumpulan data dengan melakukan penelitian langsung terhadap kondisi lingkungan objek penelitian yang mendukung kegiatan penelitian, sehingga didapat gambaran secara jelas tentang kondisi objek penelitian tersebut.

2. Wawancara 
Wawancara adalah pertemuan dua orang untuk bertukar informasi dan ide melalui tanya jawab, sehingga dapat dikonstruksikan makna dalam suatu topik tertentu.

3. Dokumentasi

Dokumentasi merupakan catatan peristiwa yang sudah berlalu. Dokumen bisa berbentuk tulisan, gambar, atau karya-karya monumental dari seseorang.

Dalam penelitian ini, teknik pengumpulan data yang digunakan adalah dokumentasi. Dokumentasi yang dilakukan dalam penelitian ini adalah dengan mengumpulkan data-data perusahaan perbankan yang terdaftar di Bursa Efek Indonesia (BEI).

\section{HASIL PENELITIAN}

1) Perhitungan Tingkat Pengembalian Saham Individu $\left(\mathbf{R}_{\mathbf{i}}\right)$

Tingkat pengembalian saham individu merupakan salah satu indikator investor dalam melakukan investasi. Tingkat pengembalian saham individu adalah besarnya keuntungan yang secara rill diterima oleh investor ketika melakukan investasi saham. Tingkat pengembalian saham individu $\left(R_{i}\right)$ dapat dihitung dengan cara melakukan perbandingan harga penutupan saham (closing pricing). Pada periode ini, yang dinotasikan dengan bulan ke-t dikurangi dengan dengan harga penutupan saham periode sebelumnya yang dinotasikan dengan bulan ke t-1 dan ditambahkan dengan deviden (yang merupakan bentuk keuntungan yang diperoleh investor dalam berinvestasi), kemudian dibagi dengan harga penutupan saham periode sebelumnya yang dinotasikan dengan bulan ke t-1.

Perhitungan tingkat pengembalian saham individu (Ri) secara keseluruhan dari masing-masing bank dapat dilihat pada perhitungan sebagai berikut:

Perhitungan $\mathrm{R}_{\mathrm{i}}$ secara rinci pada Bank $\mathrm{BNI}$ :

$\mathrm{Ri}_{2015}=\frac{(P t-P t-1)+D}{P t-1}=\frac{(4990-6100)+122.53}{6100}=-0.16188$

$\mathrm{Ri}_{2016}=\frac{(P t-P t-1)+D}{P t-1}=\frac{(5525-4990)+212.81}{4990}=0.14986$

$\mathrm{Ri}_{2017}=\frac{(P t-P t-1)+D}{P t-1}=\frac{(9900-5525)+255.55}{5525}=0.83811$

Perhitungan $\mathrm{R}_{\mathrm{i}}$ secara rinci pada Bank $\mathrm{BRI}$ adalah sebagai berikut:

$\mathrm{Ri}_{2015}=\frac{(P t-P t-1)+D}{P t-1}=\frac{(11425-11650)+311.66}{11650}=0.007439$

$\mathrm{Ri}_{2016}=\frac{(P t-P t-1)+D}{P t-1}=\frac{(11675-11425)+428.61}{11425}=0.05939$

$\mathrm{Ri}_{2017}=\frac{(P t-P t-1)+D}{P t-1}=\frac{(3640-11675)+106.75}{11675}=-0.67908$

Perhitungan $R_{i}$ secara rinci pada Bank BTN adalah sebagai berikut:

$\mathrm{Ri}_{2015}=\frac{(P t-P t-1)+D}{P t-1}=\frac{(1295-1205)+34.96}{1205}=0.10370$

$\operatorname{Ri}_{2016}=\frac{(P t-P t-1)+D}{P t-1}=\frac{(1740-1295)+49.46}{1295}=0.38182$ 
$\mathrm{Ri}_{2017}=\frac{(P t-P t-1)+D}{P t-1}=\frac{(3570-1740)+57.17}{1740}=1.08458$

Perhitungan $\mathrm{R}_{\mathrm{i}}$ secara rinci pada Bank Mandiri adalah sebagai berikut:

$\mathrm{Ri}_{2015}=\frac{(P t-P t-1)+D}{P t-1}=\frac{(9250-10775)+261.45}{10775}=-0.11727$

$\mathrm{Ri}_{2016}=\frac{(P t-P t-1)+D}{P t-1}=\frac{(11575-9250)+266.27}{9250}=0.28014$

$\mathrm{Ri}_{2017}=\frac{(P t-P t-1)+D}{P t-1}=\frac{(8000-11575)+199.03}{11575}=-0.29166$

Tabel Rekapitulasi Perhitungan Pengembalian Saham Individu

\begin{tabular}{|c|l|c|}
\hline No & Nama Emiten & $\mathbf{R}_{\mathbf{i}}$ \\
\hline 1 & Bank Negara Indonesia & 0.27536 \\
\hline 2 & Bank Rakyat Indonesia & -0.20408 \\
\hline 3 & Bank Tabungan Negara & 0.52337 \\
\hline 4 & Bank Mandiri & -0.04293 \\
\hline \multicolumn{2}{|c|}{ Jumlah } & $\mathbf{0 . 5 5 1 7 2}$ \\
\hline \multicolumn{2}{c}{ Rata-rata } & $\mathbf{0 . 1 3 7 9 3}$ \\
\hline
\end{tabular}

Berdasarkan hasil perhitungan tingkat pengembalian saham individu $\left(R_{i}\right)$ Periode 2015-2017, rata-rata tingkat pengembalian saham individu tertinggi dimiliki oleh saham Bank Tabungan Negara (BTN), yaitu sebesar $\mathbf{0 . 5 2 3 3 7}$ atau $\mathbf{5 2 . 3 3 \%}$ dan rata-rata tingkat pengembalian saham individu terendah dimiliki oleh saham Bank Mandiri , yaitu sebesar $\mathbf{- 0 . 0 4 2 9 3}$ atau $-\mathbf{4 , 2 9 \%}$.

\section{2) Perhitungan Tingkat Pengembalian Pasar ( $\mathbf{R m})$}

Tingkat pengembalian pasar adalah tingkat di mana pengembalian didasarkan pada perkembangan indeks harga saham, yang dihitung dengan membandingkan Indeks Harga Saham Gabungan akhir (IHSG $)$ dikurangi Indeks Harga Saham Gabungan periode awal (IHSG $\mathrm{t}_{-1}$ ) dibagi Indeks Harga Saham Gabungan periode awal (IHSG $\mathrm{It}_{-1}$ ). berikut:

Perhitungan $\mathrm{Rm}$ secara rinci pada tahun 2015 menggunakan rumus sebagai

Tingkat Pengembalian Pasar $(\mathrm{Rm})=\frac{I H S G t-I H S G t-1}{I H S G t-1}$

Berdasarkan hasil perhitungan untuk lebih rincinya dapat dilihat pada tabel sebagai berikut:

Tabel Tingkat Pengembalian Pasar (Rm)

\begin{tabular}{|c|c|c|c|}
\hline \multicolumn{2}{|c|}{ Bulan } & IHSG & $\mathbf{R m}$ \\
\hline \multirow{4}{*}{} & Desember & 5226.947 & ${ }^{*}$ \\
\cline { 2 - 4 } & Januari & 5289.404 & 0.01194 \\
\cline { 2 - 4 } & Februari & 5450.294 & 0.03041 \\
\cline { 2 - 4 } & Maret & 5518.675 & 0.01254 \\
\cline { 2 - 4 } & April & 5086.425 & -0.07832 \\
\cline { 2 - 4 } & Mei & 5216.379 & 0.02554 \\
\cline { 2 - 4 } & Juni & 4910.658 & -0.05860 \\
\cline { 2 - 4 } & Juli & 4802.529 & -0.02201 \\
\hline
\end{tabular}




\begin{tabular}{|c|c|c|c|}
\hline \multirow{3}{*}{2015} & Agustus & 4509.607 & -0.06099 \\
\cline { 2 - 4 } & September & 4223.908 & -0.06335 \\
\cline { 2 - 4 } & Oktober & 4455.180 & 0.05475 \\
\cline { 2 - 4 } & November & 4446.458 & -0.00195 \\
\cline { 2 - 4 } & Desember & 4593.008 & 0.03295 \\
\hline \multicolumn{2}{|c|}{ Jumlah } & -0.11709 \\
\hline
\end{tabular}

Keterangan : * adalah periode tahun sebelumnya

Perhitungan Rm secara rinci pada tahun 2016 dengan menggunakan rumus sebagai berikut:

Tingkat Pengembalian Pasar $(\mathrm{Rm})=\frac{I H S G t-I H S G t-1}{I H S G t-1}$

Untuk lebih rincinya dapat dilihat pada tabel sebagai berikut:

\section{Tabel Tingkat Pengembalian Pasar (Rm)}

\begin{tabular}{|c|c|c|c|}
\hline \multicolumn{2}{|c|}{ Bulan } & IHSG & $\mathbf{R m}$ \\
\hline \multirow{7}{*}{} & Desember & 4593.008 & ${ }^{*}$ \\
\cline { 2 - 4 } & Januari & 4615.163 & 0.00482 \\
\cline { 2 - 4 } & Februari & 4770.956 & 0.03375 \\
\cline { 2 - 4 } & Maret & 4845.371 & 0.01559 \\
\cline { 2 - 4 } & April & 4838.439 & -0.00143 \\
\cline { 2 - 4 } & Mei & 4796.727 & -0.00862 \\
\cline { 2 - 4 } & Juni & 5016.499 & 0.04581 \\
\cline { 2 - 4 } & Juli & 5215.839 & 0.03973 \\
\cline { 2 - 4 } & Agustus & 5385.922 & 0.03260 \\
\cline { 2 - 4 } & September & 5364.645 & -0.00395 \\
\cline { 2 - 4 } & Oktober & 5422.381 & 0.01076 \\
\cline { 2 - 4 } & November & 5148.910 & -0.05043 \\
\cline { 2 - 4 } & Desember & 5296.711 & 0.02870 \\
\hline \multicolumn{2}{|c|}{ Jumlah } & $\mathbf{0 . 1 4 7 3 3}$ \\
\hline
\end{tabular}

Keterangan : * adalah periode tahun sebelumnya

Berdasarkan data di atas, perhitungan $\mathrm{Rm}$ secara rinci pada tahun 2017 menggunakan rumus sebagai berikut:

Tingkat pengembalian pasar $(\mathrm{Rm})=\frac{I H S G t-I H S G t-1}{I H S G t-1}$

Berdasarkan hasil perhitungan di atas, untuk lebih rincinya dapat dilihat pada tabel sebagai berikut:

Tabel Tingkat Pengembalian Pasar (Rm)

\begin{tabular}{|c|c|c|c|}
\hline \multicolumn{2}{|c|}{ Bulan } & IHSG & $\mathbf{R m}$ \\
\hline \multirow{7}{*}{} & Desember & 5296.711 & $*$ \\
\cline { 2 - 4 } & Januari & 6355.654 & 0.19992 \\
\cline { 2 - 4 } & Februari & 5952.138 & -0.06348 \\
\cline { 2 - 4 } & Maret & 6005.784 & 0.00901 \\
\cline { 2 - 4 } & April & 5900.854 & -0.01747 \\
\cline { 2 - 4 } & Mei & 5864.059 & -0.00623 \\
\cline { 2 - 4 } & Juni & 5840.939 & -0.00394 \\
\cline { 2 - 4 } & Juli & 5829.708 & -0.00192 \\
\cline { 2 - 4 } & Agustus & 5738.155 & -.0 .01540 \\
\cline { 2 - 4 } & September & 5685.298 & -0.00921 \\
\hline
\end{tabular}




\begin{tabular}{|l|l|l|l|}
\hline \multirow{2}{*}{} & Oktober & 5568.106 & -0.02061 \\
\cline { 2 - 4 } & November & 5386.692 & -0.03258 \\
\cline { 2 - 4 } & Desember & 5294.103 & -0.01718 \\
\hline \multicolumn{2}{|c|}{ Jumlah } & $\mathbf{0 . 0 2 0 5 9}$ \\
\hline
\end{tabular}

Keterangan : * adalah periode tahun sebelumnya

Tabel Rekapitulasi Perhitungan Pengembalian Pasar (Rm)

\begin{tabular}{|c|c|c|}
\hline No & Tahun & $\mathbf{R m}$ \\
\hline 1 & 2015 & -0.11709 \\
\hline 2 & 2016 & 0.14733 \\
\hline 3 & 2017 & 0.02059 \\
\hline & Jumlah & $\mathbf{0 . 0 5 0 8 3}$ \\
\hline & Rata-rata & $\mathbf{0 . 0 0 1 4 1}$ \\
\hline
\end{tabular}

Berdasarkan hasil perhitungan tingkat pengembalian pasar $(\mathrm{Rm})$ di atas, ratarata tingkat pengembalian pasar selama 3 tahun adalah sebesar 0.001412 atau $\mathbf{0 . 1 4} \%$ dengan pembagian waktu pengamatan 36 bulan. Tingkat pengembalian pasar tertinggi selama periode 2015-2017 terjadi di bulan Januari 2017, yaitu sebesar 0.19992 atau $19.99 \%$. Sedangkan tingkat pengembalian pasar terendah terjadi di bulan April 2016, yaitu sebesar $\mathbf{- 0 . 0 0 1 4 3}$ atau $\mathbf{- 0 . 1 4 3 \%}$.

\section{3) Perhitungan Tingkat Pengembalian Bebas Resiko (Rf)}

Tingkat pengembalian bebas resiko merupakan tingkat pengembalian atas aset finansial yang tidak berisiko. Tingkat pengembalian ini merupakan dasar penetapan return minimum, karena return investasi pada sektor aset berisiko harus lebih besar dari return aset tidak berisiko. Dasar pengukuran yang digunakan dalam tingkat pengembalian ini adalah tingkat suku bunga sekuritas yang dikeluarkan oleh pemerintah, yaitu Sertifikat Bank Indonesia atau SBI, yang dapat dirumuskan sebagai berikut:

Keterangan:

$$
\mathrm{R}_{\mathrm{f}}=\frac{\sum \mathrm{SBI}}{\mathrm{N}}
$$

$\mathrm{R}_{\mathrm{f}} \quad$ : Tingkat pengembalian bebas resiko

$\mathrm{N}$ : Bulanan

Tabel Tingkat Pengembalian Bebas Risiko (Rf)

\begin{tabular}{|c|c|c|c|}
\hline \multicolumn{2}{|c|}{ Bulan } & SBI & $\mathbf{R}_{\mathbf{f}}$ \\
\hline \multirow{7}{*}{} & Januari & $7.75 \%$ & 0.0775 \\
\cline { 2 - 4 } & Februari & $7.50 \%$ & 0.075 \\
\cline { 2 - 4 } & Maret & $7.50 \%$ & 0.075 \\
\cline { 2 - 4 } & April & $7.50 \%$ & 0.075 \\
\cline { 2 - 4 } & Mei & $7.50 \%$ & 0.075 \\
\cline { 2 - 4 } & Juni & $7.50 \%$ & 0.075 \\
\cline { 2 - 4 } & Juli & $7.50 \%$ & 0.075 \\
\cline { 2 - 4 } & Agustus & $7.50 \%$ & 0.075 \\
\cline { 2 - 4 } & September & $7.50 \%$ & 0.075 \\
\cline { 2 - 4 } & Oktober & $7.50 \%$ & 0.075 \\
\cline { 2 - 4 } & November & $7.50 \%$ & 0.075 \\
\cline { 2 - 4 } & Desember & $7.50 \%$ & 0.075 \\
\hline \multirow{6}{*}{} & Januari & $7 . .25 \%$ & 0.0725 \\
\cline { 2 - 4 } & Februari & $7.00 \%$ & 0.07 \\
\cline { 2 - 4 } & Maret & $6.75 \%$ & 0.0675 \\
\cline { 2 - 4 } & April & $6.75 \%$ & 0.0675 \\
\cline { 2 - 4 } & Mei & $6.75 \%$ & 0.0675 \\
\hline
\end{tabular}




\begin{tabular}{|c|c|c|c|}
\hline \multirow[t]{7}{*}{2016} & Juni & $6.50 \%$ & 0.065 \\
\hline & Juli & $6.50 \%$ & 0.065 \\
\hline & Agustus & $5.25 \%$ & 0.0525 \\
\hline & September & $5.00 \%$ & 0.05 \\
\hline & Oktober & $4.75 \%$ & 0.0475 \\
\hline & November & $4.75 \%$ & 0.0475 \\
\hline & Desember & $4.75 \%$ & 0.0475 \\
\hline \multirow{12}{*}{2017} & Januari & $4.75 \%$ & 0.0475 \\
\hline & Februari & $4.75 \%$ & 0.0475 \\
\hline & Maret & $4.75 \%$ & 0.0475 \\
\hline & April & $4.75 \%$ & 0.0475 \\
\hline & Mei & $4.75 \%$ & 0.0475 \\
\hline & Juni & $4.75 \%$ & 0.0475 \\
\hline & Juli & $4.75 \%$ & 0.0475 \\
\hline & Agustus & $4.50 \%$ & 0.045 \\
\hline & September & $4.25 \%$ & 0.0425 \\
\hline & Oktober & $4.25 \%$ & 0.0425 \\
\hline & November & $4.25 \%$ & 0.0425 \\
\hline & Desember & $4.25 \%$ & 0.0425 \\
\hline \multicolumn{3}{|c|}{ Jumlah } & 2.2175 \\
\hline \multicolumn{3}{|c|}{ Rata-rata Bulanan } & 0.061597 \\
\hline \multicolumn{3}{|c|}{ Rf } & 0.005133 \\
\hline
\end{tabular}

Tingkat suku bunga Bank Indonesia pada bulan Januari 2015 berada di tingkat tertinggi, yaitu sebesar $\mathbf{0 . 0 7 7 5}$ atau $\mathbf{7 . 7 5 \%}$. Sedangkan tingkat suku bunga Bank Indonesia terendah terjadi pada bulan September 2017 sampai bulan Desember 2017, yaitu sebesar 0.0425 atau 4.25\%. Rata-rata tingkat suku bunga Bank Indonesia selama periode bulan Januari 2015 sampai Desember 2017 adalah sebesar 0.061597 atau $\mathbf{6 . 1 5 9 \%}$ yang kemudian nilai dibagikan dengan jumlah bulan dalam setahun, sehingga dihasilkan tingkat pengembalian risiko, yaitu:

$\mathrm{R}_{\mathrm{f}}=\frac{0.061597}{12}=\mathbf{0 . 0 0 5 1 3 3}$ atau $\mathbf{0 . 5 1 \%}$.

\section{4) Perhitungan Risiko Sistematis (Beta)}

Risiko sistematis atau Beta $(\beta)$ merupakan ukuran risiko yang berasal dari hubungan antara tingkat pengembalian suatu saham dengan tigkat pengembalian pasar, dengan kata lain beta adalah hasil bagi antara kovarian saham terhadap varian pasar.

Tabel Tingkat Risiko Sistematis (Beta)

PT. Bank Negara Indonesia (Persero) Tbk

\begin{tabular}{|c|c|c|c|c|c|c|c|c|}
\hline Tahun & $\mathbf{R}_{\mathbf{i}}$ & $\overline{\mathbf{R}} \mathbf{l}$ & $\mathbf{R}_{\mathbf{i}}-\overline{\mathbf{R}} \mathbf{l}$ & $\mathbf{R}_{\mathbf{m}}$ & $\overline{\mathbf{R m}}$ & $\mathbf{R}_{\mathbf{m}}-\overline{\mathbf{R m}}$ & $\begin{array}{c}\left(\mathbf{\mathbf { R } _ { \mathbf { i } }}-\overline{\mathbf{R} \mathbf{l}}\right)(\mathbf{R m}- \\
\overline{\mathbf{R m}})\end{array}$ & $\left(\mathbf{R}_{\mathbf{m}}-\overline{\mathbf{R m}}\right)^{\mathbf{2}}$ \\
\hline 2015 & 0.16188 & 0.27536 & -0.11348 & -0.11709 & 0.00141 & -0.1185 & 0.01345 & 0.01404 \\
\hline 2016 & 0.14986 & 0.27536 & -0.1255 & 0.14733 & 0.00141 & 0.14592 & -0.01831 & 0.02129 \\
\hline 2017 & 0.83811 & 0.27536 & 0.56275 & 0.02059 & 0.00141 & 0.01918 & 0.01079 & 0.00037 \\
\hline Jumlah & 0.82609 & & & 0.05083 & & & & \\
\hline$\overline{\mathrm{R}} \mathbf{l}$ & 0.27536 & & & 0.00141 & & & $\sigma_{i} \mathrm{~m}=0.00593$ & $\sigma^{2} \mathrm{~m}=0.0357$ \\
\hline
\end{tabular}

Besarnya Beta adalah sebagai berikut:

$$
\beta \mathrm{i}=\frac{\sigma_{\mathrm{i}} \mathrm{m}}{\sigma^{2} \mathrm{~m}} \quad=\frac{0.00593}{0.0357} \quad=0.166
$$


Tabel Tingkat Risiko Sistematis (Beta)

PT. Bank Rakyat Indonesia (Persero) Tbk

\begin{tabular}{|c|c|c|c|c|c|c|c|c|}
\hline Tahun & $\mathbf{R}_{\mathbf{i}}$ & $\overline{\mathbf{R}}$ & $\mathbf{R}_{\mathbf{i}}-\overline{\mathbf{R}} \mathbf{1}$ & $\mathbf{R}_{\mathbf{m}}$ & $\overline{\mathbf{R m}}$ & $\mathbf{R}_{\mathbf{m}}-\overline{\mathbf{R m}}$ & $\begin{array}{c}\left(\mathbf{R}_{\mathbf{i}}-\overline{\mathbf{R}} \mathbf{1}\right)(\mathbf{R m}- \\
\overline{\mathbf{R m}})\end{array}$ & $\left(\mathbf{R}_{\mathbf{m}}-\overline{\mathbf{R m}}\right)^{\mathbf{2}}$ \\
\hline 2015 & 0.00744 & -0.20408 & 0.21152 & -0.11709 & 0.00141 & -0.1185 & -0.02506 & 0.01404 \\
\hline 2016 & 0.05939 & -0.20408 & 0.26347 & 0.14733 & 0.00141 & 0.14592 & 0.03844 & 0.02129 \\
\hline 2017 & -0.67908 & -0.20408 & 0.475 & 0.02059 & 0.00141 & 0.01918 & 0.00911 & 0.00037 \\
\hline Jumlah & -0.61225 & & & 0.05083 & & & & \\
\hline$\overline{\mathrm{R}} \mathbf{1}$ & -0.20408 & & & 0.00141 & & & $\sigma_{i} \mathrm{~m}=0.02249$ & $\sigma^{2} \mathrm{~m}=0.0357$ \\
\hline
\end{tabular}

Besarnya Beta adalah sebagai berikut:

$$
\beta i=\frac{\sigma_{i} m}{\sigma^{2} \mathrm{~m}} \quad=\frac{0.02249}{0.0357}=0.629
$$

Tabel Tingkat Risiko Sistematis (Beta)

PT. Bank Tabungan Negara (Persero) Tbk

\begin{tabular}{|c|c|c|c|c|c|c|c|c|}
\hline Tahun & $\mathbf{R}_{\mathbf{i}}$ & $\overline{\mathbf{R}} \mathbf{i}$ & $\mathbf{R}_{\mathbf{i}}-\overline{\mathbf{R}} \mathbf{l}$ & $\mathbf{R}_{\mathbf{m}}$ & $\overline{\mathbf{R m}}$ & $\mathbf{R}_{\mathbf{m}}-\overline{\mathbf{R m}}$ & $\begin{array}{c}\left(\mathbf{R}_{\mathbf{i}}-\overline{\mathbf{R}} \mathbf{i}\right)(\mathbf{R m}- \\
\overline{\mathbf{R m}})\end{array}$ & $\left(\mathbf{R}_{\mathbf{m}}-\overline{\mathbf{R m}}\right)^{\mathbf{2}}$ \\
\hline 2015 & 0.10370 & 0.52337 & -0.41967 & 0.11709 & 0.00141 & -0.1185 & 0.04973 & 0.01404 \\
\hline 2016 & 0.38182 & 0.52337 & -0.14155 & 0.14733 & 0.00141 & 0.14592 & -0.02065 & 0.02129 \\
\hline 2017 & 1.08458 & 0.52337 & 0.56121 & 0.02059 & 0.00141 & 0.01911 & 0.01076 & 0.00037 \\
\hline Jumlah & 1.5701 & & & 0.05083 & & & & \\
\hline$\overline{\mathrm{R}} \mathbf{l}$ & 0.52337 & & & 0.00141 & & & $\sigma_{i} \mathrm{~m}=0.03984$ & $\sigma^{2} \mathrm{~m}=0.0357$ \\
\hline
\end{tabular}

Besarnya Beta adalah sebagai berikut:

$$
\beta \mathrm{i}=\frac{\sigma_{\mathrm{i}} \mathrm{m}}{\sigma^{2} \mathrm{~m}} \quad=\frac{0.03984}{0.0357}=1.115
$$

Tabel Tingkat Risiko Sistematis (Beta) PT. Bank Mandiri (Persero) Tbk

\begin{tabular}{|c|c|c|c|c|c|c|c|c|}
\hline Tahun & $\mathbf{R}_{\mathbf{i}}$ & $\overline{\mathbf{R}}$ & $\mathbf{R}_{\mathbf{i}}-\overline{\mathbf{R}} \mathbf{1}$ & $\mathbf{R}_{\mathbf{m}}$ & $\overline{\mathbf{R m}}$ & $\mathbf{R}_{\mathbf{m}}-\overline{\mathbf{R m}}$ & $\begin{array}{c}\left(\mathbf{R}_{\mathbf{i}}-\overline{\mathbf{R}}\right)(\mathbf{R m}-\overline{\mathbf{R m}}) \\
\left(\mathbf{R}_{\mathbf{m}}-\overline{\mathbf{R m}}\right)^{\mathbf{2}}\end{array}$ \\
\hline 2015 & -0.11727 & -0.04293 & -0.07434 & -0.11709 & 0.00141 & -0.1185 & 0.00388 & 0.01404 \\
\hline 2016 & 0.28014 & -0.04293 & 0.32307 & 0.14733 & 0.00141 & 0.14592 & 0.04714 & 0.02129 \\
\hline 2017 & 0.29166 & -0.04293 & -0.24873 & 0.02059 & 0.00141 & 0.01918 & -0.00477 & 0.00037 \\
\hline Jumlah & -0.12879 & & & 0.05083 & & & & \\
\hline$\overline{\mathrm{R}} \mathbf{l}$ & -0.04293 & & & 0.00141 & & & $\sigma_{i} \mathrm{~m}=0.04625$ & $\sigma^{2} \mathrm{~m}=0.0357$ \\
\hline
\end{tabular}

Besarnya Beta adalah sebagai berikut:

$$
\beta \mathrm{i}=\frac{\sigma_{\mathrm{i}} \mathrm{m}}{\sigma^{2} \mathrm{~m}} \quad=\frac{0.04625}{0.0357}=1.295
$$

Tabel Rekapitulasi Tingkat Risiko Sistematis (Beta)

\begin{tabular}{|c|l|c|}
\hline No & Nama Emiten & Beta \\
\hline 1 & Bank Negara Indonesia & 0.166 \\
\hline 2 & Bank Rakyat Indonesia & 0.629 \\
\hline 3 & Bank Tabungan Negara & 1.115 \\
\hline 4 & Bank Mandiri & 1.295 \\
\hline
\end{tabular}

Berdasarkan hasil perhitungan beta, dapat dilihat bahwa saham Bank Mandiri memiliki nilai beta tertinggi pada periode tersebut dibandingkan nilai beta sahamsaham perusahaan lainnya yakni sebesar $\mathbf{1 . 2 9 5}$, hal ini menunjukkan bahwa saham 
Bank Mandiri merupakan saham yang cukup aktif dalam mengikuti perubahan pasar. Sebaliknya saham Bank Negara Indonesia (BNI) yang memiliki nilai beta terendah, yaitu 0.166 .

\section{5) Perhitungan Tingkat Pengembalian yang Diharapkan $\mathbf{E}\left(\mathbf{R}_{\mathbf{i}}\right)$}

Tingkat pengembalian yang diharapkan merupakan bagian dari tingkat keuntungan aktual yang diperkirakan atau diharapkan oleh para investor di masa yang akan datang, terhadap investasi yang dilakukan. Dengan menghitung tingkat pengembalian yang diharapkan, yaitu menggunakan rumus $E\left(R_{i}\right)=R_{f}+\left\{E R_{m}\right)-$ $\mathrm{Rf}\} \beta \mathrm{i}$. Hasil perhitungan tingkat pengembalian yang diharapkan dari 4 perusahaan dapat dilihat pada tabel 19 di bawah ini:

Tabel Tingkat Pengembalian yang Diharapkan $\mathbf{E}\left(\mathbf{R}_{\mathbf{i}}\right)$

\begin{tabular}{|c|c|c|c|c|c|c|c|}
\hline No & $\begin{array}{c}\text { Kode } \\
\text { Emiten }\end{array}$ & $\mathbf{R}_{\mathbf{f}}$ & $\mathbf{E}\left(\mathbf{R}_{\mathbf{m}}\right)$ & $\begin{array}{c}\text { Beta } \\
(\boldsymbol{\beta})\end{array}$ & $\mathbf{E}\left(\mathbf{R}_{\mathbf{m}}\right)-\mathbf{R}_{\mathbf{f}}$ & $\left\{\mathbf{E}\left(\mathbf{R}_{\mathbf{m}}\right)-\mathbf{R}_{\mathbf{f}}\right\} \boldsymbol{\beta}_{\mathbf{i}}$ & $\mathbf{E}\left(\mathbf{R}_{\mathbf{i}}\right)$ \\
\hline 1 & Bank BNI & 0.005133 & 0.00141 & 0.166 & -0.003723 & -0.00062 & 0.00575 \\
\hline 2 & Bank BRI & 0.005133 & 0.00141 & 0.629 & -0.003723 & -0.00234 & 0.00747 \\
\hline 3 & Bank BTN & 0.005133 & 0.00141 & 1.115 & -0.003723 & -0.00415 & 0.00928 \\
\hline 4 & Bank Mandiri & 0.005133 & 0.00141 & 1.295 & -0.003723 & -0.00482 & 0.00995 \\
\hline \multicolumn{6}{|c|}{ Jumlah } & $\mathbf{0 . 0 3 2 4 5}$ \\
\hline \multicolumn{6}{|c|}{ E(Ri) } & $\mathbf{0 . 0 0 8 1 1}$ \\
\hline
\end{tabular}

Berdasarkan hasil perhitungan di atas, tingkat pengembalian yang diharapkan $E\left(R_{i}\right)$ saham Bank Mandiri memiliki tingkat pengembalian saham yang diharapkan tertinggi yaitu sebesar $\mathbf{0 . 0 0 9 9 5}$ atau $\mathbf{0 . 9 9 5 \%}$. Sedangkan tingkat pengembalian yang diharapkan terendah, yaitu pada saham Bank Negara Indonesia (BNI) yaitu $\mathbf{0 . 0 0 5 7 5}$ atau $0.575 \%$.

\section{6) Klasifikasi Saham Efisien}

Saham efisien adalah saham dengan tingkat pengembalian saham individu lebih besar daripada tingkat pengembalian yang diharapkan [(Ri) > E(Ri)]. Sedangkan saham tidak efesien adalah saham dengan tingkat pengembalian individu lebih kecil daripada tingkat pengembalian yang diharapkan $[(R i)<E(R i)]$. Keputusan terhadap saham yang efisien adalah mengambil atau membeli saham, sedangkan keputusan terhadap saham tidak efisien adalah menjual saham sebelum harga saham turun.

Tabel Evaluasi Saham Periode 2015-2017

\begin{tabular}{|c|c|c|c|c|c|}
\hline No & Nama Emiten & $\mathbf{R i}$ & $\mathbf{E}(\mathbf{R i})$ & Selisih & Evaluasi Saham \\
\hline 1 & Bank Negara Indonesia & 0.27536 & 0.00575 & 0.26961 & Efisien \\
\hline 2 & Bank Rakyat Indonesia & -0.20408 & 0.00747 & -0.21155 & Tidak Efisien \\
\hline 3 & Bank Tabungan Negara & 0.52337 & 0.00928 & 0.51409 & Efisien \\
\hline 4 & Bank Mandiri & -0.04293 & 0.00995 & -0.05288 & Tidak Efisien \\
\hline
\end{tabular}

Berdasarkan informasi tabel di atas, dapat dilihat bahwa 2 saham perusahaan perbankan, yaitu Bank Negara Indonesia (BNI) dan Bank Tabungan Negara (BTN) periode 2015-2017 memiliki tingkat pengembalian saham individu lebih besar daripada tingkat pengembalian yang diharapkan $[(\mathrm{Ri})>E(R i)]$. Sedangkan 2 saham perbankan, yaitu Bank Rakyat Indonesia (BRI) dan Bank Mandiri pada periode 20152017 memiliki tingkat pengembalian individu lebih kecil daripada tingkat pengembalian yang diharapkan $[(\mathrm{Ri})<\mathrm{E}(\mathrm{Ri})]$. 


\section{E. PEMBAHASAN}

\section{Tingkat Pengembalian Saham Individu (Ri)}

Berdasarkan hasil perhitungan, tingkat pengembalian saham individu (Ri) Periode 2015-2017 menunjukkan bahwa dari 4 sampel penelitian, terdapat 2 perusahaan perbankan, yaitu Bank Negara Indonesia (BNI) dan Bank Tabungan Negara (BTN) yang memiliki rata-rata tingkat pengembalian positif [(Ri) >0], dan 2 perusahaan perbankan, yaitu Bank Rakyat Indonesia (BRI) dan Bank Mandiri yang memiliki rata-rata tingkat pengembalian negatif $[(\mathrm{Ri})<0]$. Rata-rata tingkat pengembalian saham individu tertinggi dimiliki oleh saham Bank Tabungan Negara (BTN), yaitu sebesar $\mathbf{0 . 5 2 3 3 7}$ atau $\mathbf{5 2 . 3 3 \%}$ dan rata-rata tingkat pengembalian saham individu terendah dimiliki oleh saham Bank Mandiri , yaitu sebesar $\mathbf{- 0 . 0 4 2 9 3}$ atau $-4,29 \%$.

Nilai rata-rata tingkat pengembalian saham setiap tahun selama periode penelitian, menunjukan pergerakan yang tidak berpola. Ini karena pada saat kondisi pasar pasar melemah (bearish) dan ada saat kondisi pasar menguat (bullish) di sepanjang periode 2012-2014. Kondisi pasar melemah (bearish) menggambarkan suatu situasi pasar yang sedang tidak bergairah, lambat dan kondisi pasar yang secara umum didominasi oleh penjual, sehingga harga-harga saham mengalami penurunan. Sedangkan kondisi (bullish) menggambarkan suatu situasi pasar yang sedang bergairah, bergerak cepat dan kondisi pasar yang secara umum didominasi oleh pembeli, sehingga mengakibatkan harga-harga saham mengalami kenaikan.

\section{Tingkat Pengembalian Pasar (Rm)}

Hasil perhitungan tingkat pengembalian pasar $(\mathrm{Rm})$ di atas rata-rata tingkat pengembalian pasar selama 3 tahun adalah sebesar 0.001412 atau $0.14 \%$ dengan pembagian waktu pengamatan 36 bulan. Tingkat pengembalian pasar tertinggi selama periode 2015-2017 terjadi di bulan Januari 2017, yaitu sebesar $\mathbf{0 . 1 9 9 9 2}$ atau 19.99\%. Hal ini menunjukkan bahwa kondisi perdagangan di pasar modal sangat aktif. Sedangkan tingkat pengembalian pasar terendah terjadi di bulan April 2016, yaitu sebesar $\mathbf{- 0 . 0 0 1 4 3}$ atau $\mathbf{- 0 . 1 4 3 \%}$. Hal ini menunjukkan bahwa perdagangan di pasar modal mengalami kelesuan. Tingkat pengembalian pasar dapat dijadikan sebagai dasar pengakuan performance investasi saham. Berdasarkan perhitungan tingkat pengembalian pasar dan tingkat pengembalian bebas risiko, bahwa dapat dikatakan bahwa pada periode 2015-2017 tingkat pengembalian pasar lebih kecil daripada tingkat pengembalian bebas risiko $(0.00141<0.005133)$, keadaan ini menunjukan performance investasi belum dikatakan baik.

\section{Tingkat Pengembalian Bebas Risiko (Rf)}

Tingkat suku bunga Bank Indonesia pada bulan Januari 2015 berada di tingkat tertinggi, yaitu sebesar $\mathbf{0 . 0 7 7 5}$ atau $\mathbf{7 . 7 5 \%}$. Sedangkan tingkat suku bunga Bank Indonesia terendah terjadi pada bulan September 2017 sampai bulan Desember 2017, yaitu sebesar $\mathbf{0 . 0 4 2 5}$ atau $\mathbf{4 . 2 5 \%}$. Rata-rata tingkat suku bunga Bank Indonesia selama periode bulan Januari 2015 sampai Desember 2017 adalah sebesar $\mathbf{0 . 0 6 1 5 9 7}$ atau $\mathbf{6 . 1 5 9 \%}$ yang kemudian nilai dibagikan dengan jumlah bulan dalam setahun, sehingga dihasilkan tingkat pengembalian risiko, yaitu 0.005133 atau $0.51 \%$.

Naiknya suku bunga bank mengakibatkan peningkatan pada tingkat pengembalian bebas risiko, hal ini mengakibatkan penurunan tingkat harga saham. Hal tersebut terjadi karena ketika suku bunga naik, maka investor lebih memilih 
menginvestasikan modalnya ke pasar uang, karena memberikan tingkat pengembalian yang tinggi dan pasar uang merupakan tempat investasi yang lebih aman. Apabila suku bunga turun, maka hal tersebut akan memicu investor untuk menanamkan modal di pasar modal.

\section{Risiko Sistematis (Beta)}

Berdasarkan hasil perhitungan beta, dapat dilihat bahwa dari 4 sampel saham perusahaan perbankan milik BUMN Periode 2015-2017 terdapat 2 perusahaan perbankan yang memili nilai beta lebih dari satu $(\beta i>1)$, yaitu Bank Tabungan Negara(BTN) dan Bank Mandiri. Hal ini menunjukkan bahwa harga saham perusahaan lebih mudah berubah dibandingkan indeks pasar. Selanjutnya terdapat 2 perusahaan perbankan yang memili nilai beta kurang dari satu $(\beta i<1)$ yaitu Bank Negara Indonesia (BNI) dan Bank Rakyat Indonesia (BRI). Hal ini menunjukkan harga saham perusahaan tidak mudah berubah dibandingkan indeks pasar. Saham Bank Mandiri memiliki nilai beta tertinggi pada periode tersebut dibandingkan nilai beta saham-saham perusahaan lainnya yakni sebesar 1.295, hal ini menunjukkan bahwa saham Bank Mandiri merupakan saham yang cukup aktif dalam mengikuti perubahan pasar. Sebaliknya saham Bank Negara Indonesia (BNI) yang memiliki nilai beta terendah, yaitu $\mathbf{0 . 1 6 6}$.

\section{Tingkat Pengembalian yang Diharapkan E(Ri)}

Berdasarkan hasil perhitungan, tingkat pengembalian yang diharapkan $E\left(R_{i}\right)$ saham Bank Mandiri memiliki tingkat pengembalian saham yang diharapkan tertinggi yaitu sebesar 0.00995 atau $\mathbf{0 . 9 9 5 \%}$. Sedangkan tingkat pengembalian yang diharapkan terendah, yaitu pada saham Bank Negara Indonesia (BNI) sebesar 0.00575 atau $0.575 \%$.

Berdasarkan pernyataan di atas, dapat disimpulkan bahwa besar kecilnya tingkat pengembalian yang diharapkan bergantung pada besar kecilnya nilai beta yang merupakan risiko. Hal ini dapat ditunjukkan dengan nilai beta pada saham Bank Negara Indonesia (BNI) menempati posisi yang paling rendah di antara sahamsaham bank milik Badan Usaha Milik Negara (BUMN), sehingga pada perhitungan tingkat pengembalian yang diharapkan Bank Negara Indonesia (BTN) juga menempati posisi yang paling rendah, dan saham Bank Mandiri pada perhitungan nilai beta menempati posisi paling tinggi di antara saham bank milik Badan Usaha Milik Negara (BUMN), sehingga pada perhitungan tingkat pengembalian yang diharapkan Bank Mandiri juga menempati posisi yang paling tinggi. Hal ini menunjukkan bahwa tinggi rendahnya atau besar kecilnya tingkat pengembalian yang diharapkan tergantung pada besar kecilnya risiko dari saham tersebut dengan ditunjukan nilai beta, atau dengan kata lain terdapat hubungan positif, searah, atau linier antara risiko sistematis beta dengan tingkat pengembalian yang diharapkan.

\section{Penggolongan Saham Efisien}

Berdasarkan hasil evaluasi periode 2015-2017, dapat dilihat bahwa dari 4 sampel penelitian terdapat dua perusahaan perbankan, yaitu Bank Negara Indonesia (BNI) dan Bank Tabungan Negara (BTN) yang memiliki tingkat pengembalian saham individu lebih besar, dibandingkan dengan tingkat pengembalian yang diharapkan $[(\mathrm{Ri})>\mathrm{E}(\mathrm{Ri})]$. Hal ini dapat dikatakan bahwa dua saham perusahaan perbankan tersebut termasuk saham efisien, sehingga sangat baik untuk para investor melakukan investasinya pada 2 perusahaan perbankan tersebut. 
Sedangkan pada dua perusahaan perbankan yaitu Bank Rakyat Indonesia (BRI) dan Bank Mandiri yang memiliki tingkat pengembalian saham individu lebih kecil dibandingkan dengan tingkat pengembalian yang diharapkan $[(\mathrm{Ri})<\mathrm{E}(\mathrm{Ri})]$. Hal ini dapat dikatakan bahwa 2 saham perusahaan perbankan tersebut termasuk saham tidak efisien, sehingga belum dapat dikatakan baik untuk para investor melakukan investasinya pada 2 perusahaan perbankan tersebut pada periode ini.

\section{F. KESIMPULAN DAN SARAN}

1) Kesimpulan

Berdasarkan hasil analisis dan pembahasan yang telah dilakukan, maka peneliti mengambil beberapa kesimpulan sebagai berikut:

a. Pada periode 2015-2017 didapatkan rata-rata return saham individual 4 perusahaan perbankan yang menjadi sampel penelitian adalah sebesar 0.13793 . Selanjutnya rata-rata tingkat pengembalian pasar adalah sebesar 0.00141 . Sedangkan rata-rata tingkat pengembalian bebas risiko adalah sebesar 0.005133 dengan kata lain bahwa pada periode 2015-2017 tingkat pengembalian pasar lebih kecil daripada tingkat pengembalian bebas risiko $(0.00141<0.005133)$. Kondisi ini menggambarkan bahwa performance investasi belum dikatakan baik.

b. Pada penelitian ini, didapatkan bahwa pada periode 2015-2017 rata-rata risiko 4 perusahaan perbankan milik Badan Usaha Milik Negara (BUMN) terdapat 2 perusahaan perbankan dengan risiko di bawah $1(\beta i<1)$, yaitu Bank BNI dan Bank BRI selanjutnya 2 perusahaan perbankan dengan risiko di atas $1(\beta i>1)$ yaitu Bank BTN dan Mandiri.

c. Saham efisien merupakan saham yang memiliki return individu (Ri) lebih besar daripada tingkat pengembalian yang diharapkan $[E(R i)]$, sebaliknya saham yang tidak efisien adalah saham yang memiliki return individu (Ri) lebih kecil daripada tingkat pengembalian yang diharapkan $[E(R i)]$.

Dalam penelitian ini, bahwa 2 saham perusahaan perbankan yaitu bank BNI dan BTN memiliki tingkat pengembalian saham individu lebih besar dibandingkan dengan tingkat pengembalian yang diharapkan, yaitu $[(\mathrm{Ri})>\mathrm{E}$ (Ri)] termasuk dalam saham efisien, sehingga sangat baik untuk para investor melakukan investasinya. Sedangkan pada 2 perusahaan perbankan, yaitu Bank Rakyat Indonesia (BRI) dan Bank Mandiri yang memiliki tingkat pengembalian saham individu lebih kecil dibandingkan dengan tingkat pengembalian yang diharapkan, yaitu $[(\mathrm{Ri})<\mathrm{E}(\mathrm{Ri})]$. Hal ini menunjukkan bahwa 2 saham perusahaan perbankan tersebut termasuk saham tidak efisien, sehingga belum dapat dikatakan baik untuk para investor melakukan investasinya. Pada periode 2015-2017, saham Bank Tabungan Negara (BTN) merupakan saham yang paling efisien di antara saham-saham perusahaan perbankan milik Badan Usaha Milik Negara (BUMN) yang lain, karena memiliki selisih antara return inidividu (Ri) dan tingkat pengembalian yang diharapkan $\mathrm{E}(\mathrm{Ri})$ tertinggi yaitu sebesar 0.51409 .

2) Saran

Berdasarkan simpulan di atas, peneliti memberikan saran-saran yang dapat bermanfaat bagi para investor dan peneliti selanjutnya, yaitu sebagai berikut:

a. Bagi Investor

Penelitian ini diharapkan dapat dijadikan referensi dan tambahan informasi bagi para investor maupun calon investor, yang akan melakukan investasi matang 
atas berbagai macam kemungkinan risiko yang akan dihadapi dan tingkat keuntungan yang akan diperolehnya di masa mendatang.

b. Untuk kurun waktu yang akan datang, seorang investor dapat berinvestasi pada saham-saham di sektor perbankan. Hal ini masih relevan selama kondisi pasar belum menunjukkan perubahan yang besar dari kondisi saat ini yaitu periode 2015-2017.

c. Bagi perusahaan yang sahamnya belum termasuk kategori saham efisien pada periode penelitian ini, dapat melakukan perbaikan kinerja perusahaannya agar performa sahamnya meningkat.

\section{DAFTAR PUSTAKA}

Fahmi, Irham. 2013. Pengantar Pasar Modal. Bandung: Alfabeta.

Fauzi, Muchamad. 2010. Metode Penelitian Kuantitatif. Semarang: Walisongo Press.

Hadi, Yovi Levianti. 2013. Teori Portofolio dan Analisis Investasi. Bandung: Alfabeta.

Halim, Abdul. 2015. Analisis Investasi di Aset Keuangan. Jakarta: Mitra Wacana Media.

Husnan, Suad. 2012. Dasar-dasar Teori Portofolio dan Analisis Sekuritas. Yogyakarta: STIM YKPN.

Irawati, Dewi . 2010. Analisis Metode Capital Asset Pricing Model (CAPM) Sebagai Dasar Pengambilan Keputusan Investasi Pada Perusahaan Perbankan yang Tercatat di Bursa Efek Indonesia. Malang: Universitas Muhammadiyah Malang. (Tidak Untuk Dipublikasikan ).

Ismail. 2011. Manajemen Perbankan Dari Teori Menuju Aplikasi. Jakarta: Kencana Predana Media Grup.

Jagiyanto. 2014. Teori Portofolio dan Analisis Investasi. BPFE: Yogyakarta.

2016. Teori Portofolio dan Analisis Investasi. BPFE: Yogyakarta.

Kasmir. 2014. Dasar-Dasar Perbankan Edisi Revisi. Jakarta: PT. Raja Grafindo Persada.

Nasuha, Rizky. 2013. Analisis Metode Capital Asset Pricing Model Dalam Upaya Pengambilan Keputusan Terhadap Investasi Saham Studi Saham-Saham Perusahaan Sektor Properti dan Real Estate di Bursa Efek Indonesia (BEI) Periode 2014-2016. Malang: Fakultas IImu Administrasi Universitas Brawijaya Malang. (Tidak Untuk Dipublikasikan).

Sekarwati, Herarum. 2016. Penggunaan Metode Capital Asset Pricing Model Dalam Menentukan Keputusan Berinvestasi Saham (Studi pada Saham Indeks 
Kompas 100 di Bursa Efek Indonesia). Yogyakarta: Universitas Negeri Yogyakarta. (Tidak Untuk Dipublikasikan).

Sugiyono. 2017. Metode Penelitian Pendidikan. Pendekatan Kuantitatif, Kualitatif, dan $R \& D$. Bandung: Alfabeta.

Sujarweni. 2014. Metode Penelitian. Jakarta: Rineka Cipta.

Sunariyah. 2011. Pengantar Pengetahuan Pasar Modal Edisi Keenam, Yogyakarta: UP- STIM YKPN.

Supriyati, Tri. 2015. Analisa Pengambilan Keputusan Investasi Saham dengan Pendekatan Capital Asset Pricing Model (CAPM) pada Perusahaan Perbankan yang Terdaftar di Bursa Efek Indonesia (BEI). Palembang: Universitas PGRI Palembang. (Skripsi Tidak Dipublikasikan).

Tandelilin, Eduardus. 2010. Analisis Investasi dan Manajemen Portofolio Edisi Pertama. Yogyakarta: BPFE UGM.

Utami, Endah Tri.2010. Cara Cerdas Berinvestasi via Online Trading. Jakarta: Transmedia Pustaka. 